\title{
Climate-Induced Food Crisis in Africa: Integrating Policy and Adaptation
}

\author{
David O. Chiawo and Verrah A. Otiende
}

\section{Contents}

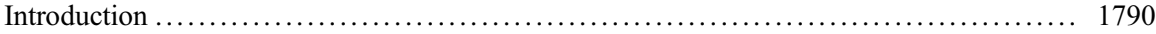

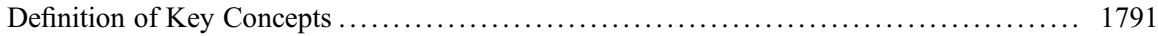

Methods and Research Design .......................................... 1792

Patterns of Climate-Induced Food Crisis and Adaptation in Africa .................... 1792

Spatial Trends of Food Crisis in Africa ................................... 1792

Climate Change Adaptation Initiatives in Africa .............................. 1794

Policy Initiatives for Climate Change Adaptation .............................. 1800

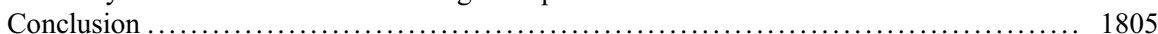

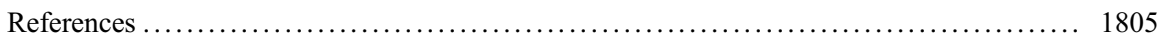

\section{Abstract}

Climate change threatens development and economic growth in Africa. It increases risks for individuals and governments with unprecedented negative impacts on agriculture. Specifically, climate change presents a major threat to food security in Africa for the long term due to the low adaptive capacity to deal with successive climate shocks. There is a need for greater awareness of the trends of food crisis patterns and adaptive initiatives. The objective of this chapter was to analyze the trends of the food crisis in Africa within the past 10 years and adaptive initiatives. Quantitative data analyzed for food security indicators were

This chapter was previously published non-open access with exclusive rights reserved by the Publisher. It has been changed retrospectively to open access under a CC BY 4.0 license and the copyright holder is "The Author(s)". For further details, please see the license information at the end of the chapter.

D. O. Chiawo $(\square)$

Strathmore University, Nairobi, Kenya

e-mail: dchiawo@strathmore.edu

\section{A. Otiende}

Pan African University Institute for Basic Sciences Technology and Innovation, Nairobi, Kenya 
obtained from the United Nations Food and Agriculture Organization (FAO) and World Development Indicators (WDI) available at the Environment and Climate Change data portal. Policy and adaptation measures related to climate change were reviewed in 26 countries in Africa, with the view to highlight their integrative nature in enhancing food security. High prevalence of undernourishment was observed in six countries, all in sub-Saharan Africa (SSA) including Chad, Liberia, Central African Republic, The Democratic Republic of the Congo, Zambia, and Zimbabwe. Countries with a high land acreage under cereal production recorded reduced undernourishment. Niger demonstrated effective adaptation for food security by registering the highest crop production index in extreme climate variability. However, Kenya appears to be the most predisposed by registering both high climate variability and below average crop production index. It is observed that diversification and technology adoption are key strategies applied across the countries for adaptation. However, the uptake of technology by smallholder farmers is still low across many countries in SSA.

\section{Keywords}

Climate change adaptation ' Climate change adaptation policy - Food security $\cdot$ Smallholder farmers $\cdot$ Africa

\section{Introduction}

Climate change threatens development and economic growth in Africa. It will increase risks for individuals and governments with unprecedented negative impacts across all sectors of the economy. Specifically, climate change presents a major threat to food security in Africa for the coming decade due to low adaptive capacity to deal with successive climate shocks, despite the trend of the rapid pace of population growth. Population growth in sub-Saharan Africa is likely to experience by far the most rapid relative expansion more than doubling to 2.0 billion by 2050 (Bongaarts 2009). The positive population growth is attributed to technology transitions in health care; however, it is expected to generate increased demand for agricultural land and forest products (Brandt et al. 2017), calling for a matching assemblage of technology and policies to enhance food security to limit the possible impact to the environment.

An overwhelming majority of hungry people are found in developing countries, particularly in Africa (Abegunde et al. 2019). With increasing recognition of present and future impacts of climate change, the United Nations Framework Convention on Climate Change (UNFCC 2006) has identified the poorest people living in developing countries as the most vulnerable due to their dependence on natural resources and rain-fed agriculture for survival. However, agriculture remains the dominant employer of rural residents in Africa (e.g., Kalungu and Leal Filho 2018; Belay et al. 2017; Mutunga et al. 2017; Cobbinah and Anane 2016). Smallholder farming creates opportunities for an estimated 175 million people in Africa, of which about $70 \%$ are 
women (AGRA 2014). Across the world, smallholder farmers are considered to be disproportionately vulnerable to climate change because changes in temperature, rainfall, and the frequency or intensity of extreme weather events directly affect their crop and animal productivity (Vignola et al. 2015).

The vulnerability of smallholder farmers is a concern because they represent $85 \%$ of the world's farmers and provide more than $80 \%$ of the food consumed in the developing world; therefore, what happens to smallholder farmers will have significant social, economic, and environmental consequences globally (Vignola et al. 2015). By their sheer numbers and with optimal productivity, they would have a huge impact in addressing food insecurity (Abegunde et al. 2019), but because of low resource capacity, inadequate skills, and lack of enabling policies, they remain susceptible particularly to climate variability in Africa. Climate change adaptation has become necessary to alleviate the impacts of extreme weather events, especially on rural farmers whose primary livelihood is climate dependent (Cobbinah and Anane 2016).

There is a looming food security crisis in Africa for the next decade due to limited adaptive approaches to extreme climatic conditions of drought, floods, and high temperatures due to climate change (Abegunde et al. 2019). IPCC special report suggested that an increase by $2{ }^{\circ} \mathrm{C}$ could exacerbate food crises with crops under rain-fed agriculture dropping by $50 \%$ in some African countries by 2020 (IPCC 2018). The current and future impacts of climate change have attracted increasing scholarly work on climate change adaptation (Cobbinah and Anane 2016; Burnham and Ma 2016; Lasco et al. 2014) and its widespread incorporation into national policy and international dialogue (IPCC 2007, 2013). Responding to the effects of climate change requires the continuous development of new adaptive initiatives and improvement of the existing ones and enhancing their widespread adoption by smallholder farmers (Kalungu and Leal Filho 2018). Pursuing appropriate adaptation initiatives in line with realities in Africa is thus vital. A recent study highlighted a positive link between public response and the capacity of farmers to adapt to climate change in sub-Saharan Africa (Abegunde et al. 2019). However, a gap exists in critical review of the role of existing climate change adaptation policies in enhancing the adoption of the initiatives. The objective of this chapter is to analyze the spatiotemporal trends of the food crisis in Africa and adaptive approaches with the view to model a framework for climate change adaptation pathway for Africa.

\section{Definition of Key Concepts}

This chapter uses the definition of food security by the United Nations Food and Agriculture Organization (FAO) as food is available at all times; that all persons have means of access to it; that is nutritionally adequate in terms of quantity, quality, and variety; and that it is acceptable within the given culture (Silvestri et al. 2015; Conceição et al. 2016; Luximon and Nowbuth 2010). The chapter defines climate change as a change of climate that is attributed directly or indirectly to human activity that alters the composition of the global atmosphere that is in addition to natural climate variability observed over comparable periods (UNFCC 2006). The 
chapter adopts the meaning of climate change adaptation (Mutunga et al. 2017) in that adaptation to climate change is the adjustment in natural or human systems in response to actual or expected climatic stimuli or their effects, which moderates harm or exploit beneficial opportunities.

\section{Methods and Research Design}

The analysis was based on four World Bank food security indicators including average prevalence of undernourishment, land under cereal production, extreme climate change variability, and crop production index. Dataset was obtained from World Development Indicators (WDI) (WDI available at Environment and Climate Change data portal http://africaclimate.opendataforafrica.org/kaoatif/world-development-indi cators-wdi). R was for spatial analysis (R Core Team 2020) using shapefile for 52 African countries from Map Library (Map Library is available at http://www. maplibrary.org/library/stacks/Africa/index.htm). Both dataset and shapefile used are licensed under CC BY 4 and are open for public access (Publicly available for any use according to open data standards and licenses under the Creative Commons Attribution 4.0 International license (CC-BY 4.0)). Adaptive and policy strategies applied across Africa were reviewed at local, national, and regional scales. Countries were selected based on the undernourished index and vulnerability to climate change. Spatial patterns were analyzed for undernourishment, land under cereal production, crop production index, and climate change variability in all the 52 African countries according to the shapefile. The spatial patterns were used to identify the countries for review of adaptation and policy strategies. High undernourishment prevalence countries above $40 \%$ and low prevalence countries below $10 \%$ were selected for review of adaptation and policy strategies for comparison and criticism. Additional counties for review of adaptation and policy were selected based on vulnerability to climate change, low or high crop production index, and landmass under cereal production (Figs. 1 and 2). A total of 26 countries were reviewed across Africa with a larger proportion in SSA. The approach presents a conceptual model integrating climate change adaptation and policy initiatives to illustrate the effective pathway to climate change adaptation in Africa for food security.

\section{Patterns of Climate-Induced Food Crisis and Adaptation in Africa}

This section is structured in three parts: the first part presents the results of spatial analysis of food security in Africa for the last 10 years, adaptation initiatives in the second part, and policy initiatives in the third part.

\section{Spatial Trends of Food Crisis in Africa}

The prevalence of undernourishment $(\mathrm{PoU})$ is defined by FAO as an estimate of the proportion of the population whose habitual food consumption is insufficient to 

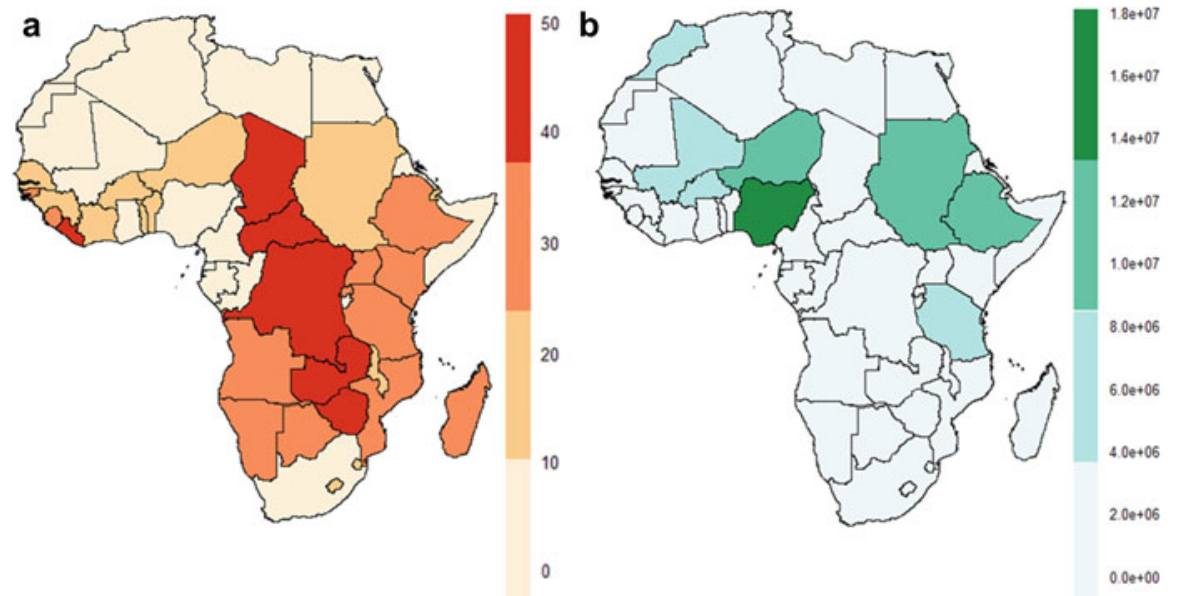

Fig. 1 Spatial patterns of climate-induced-food crisis in Africa. (a) Average prevalence of undernourishment (\% of the population) in Africa for the period 2009-2017. (b) Land under cereal production (hectares) for the period 2009-2017 (Authors own)
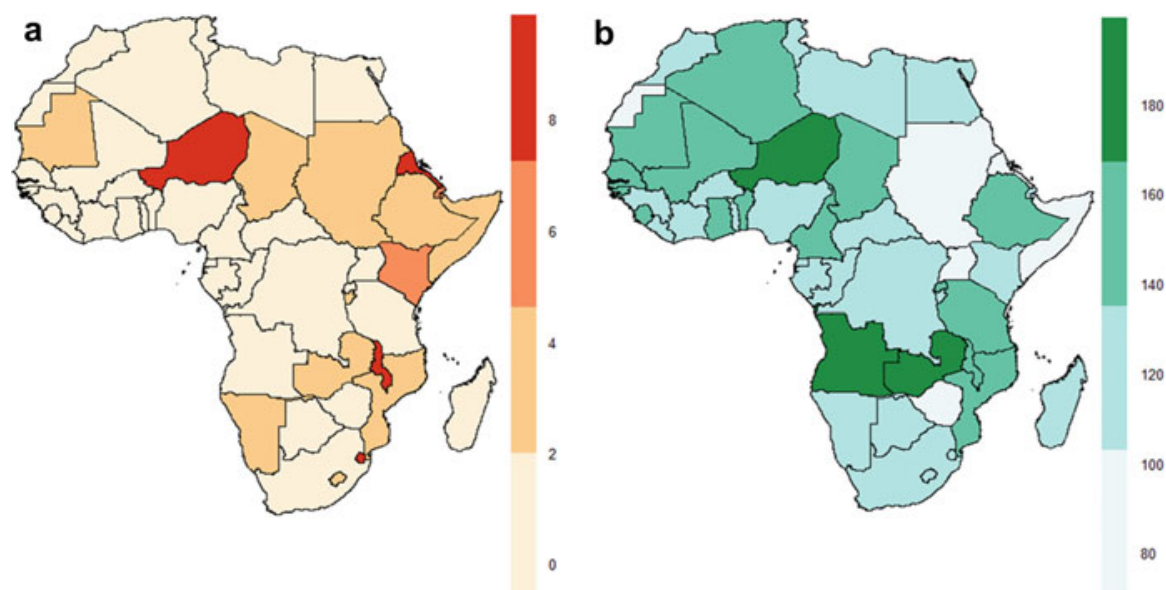

Fig. 2 Spatial patterns of extreme climate change variability and crop production index in Africa. (a): Droughts, floods, extreme temperatures (\% of the population). (b): Crop production index for the period 2009-2016 (Authors own)

provide the dietary energy levels that are required to maintain a normal active and healthy life. The spatial trends of undernourishment in the last 10 years reveal a high prevalence of $40-50 \%$ in six countries (6), all in sub-Sahara Africa (SSA) including Chad in the Sahel and Central Africa, Liberia in West Africa, Central African Republic and the Democratic Republic of the Congo in Central Africa, and Zambia and Zimbabwe in Sothern Africa. Low prevalence is observed in North Africa with all countries registering below $10 \%$ of undernourishment (Fig. 1a). 
Countries with a high land acreage under cereal production recorded reduced undernourishment (Fig. 1a). Nigeria had the largest landmass under cereal production in the last 10 years with a peak of 18 million hectares (Fig. 1b). Other countries above the average of landmass under cereal include Sudan, Ethiopia, Tanzania, and Niger. It is predicted that a possible cross-border trade policy or intercountry relationship between neighboring countries could be influencing the production of cereals, e.g., Sudan and Ethiopia and Niger, Nigeria, Burkina Faso, and Mali. Most countries in Southern Africa have lower than average landmass under cereal production. Although South Africa has below average landmass under cereals, the undernourishment prevalence was still low for the period of analysis, a pointer toward effective diversification or technology adoption in climate change adaptation (Fig.1b).

High incidences of extreme conditions due to climate change including droughts, floods, and extreme temperatures are high in four countries that experienced the highest extreme climate change variability in the last 10 years including Niger, Eritrea, Malawi, and Swaziland. However, these countries registered average to high crop production index an indication of effective climate change adaptation. Kenya appears to be more predisposed to extreme climate change variability in East Africa (Fig. 2a). The leading countries in Africa in crop production are Niger, Angola, and Zambia. A good example of how effective climate change adaptation can lead to food security is Niger, which experiences the highest in extreme climate variability, but registers the highest crop production index. It is important to note that Nigeria had a higher landmass under cereal production (Figs. 1b and 2b), but Niger registered a higher crop production index in the same period pointing toward possibilities of application of multiple adaptive initiatives beyond increasing acreage. Sudan, South Sudan, Eritrea, Somalia, Zimbabwe, and Western Sahara are African countries with the lowest crop production index despite experiencing average and below of extreme climate change variability (Fig. 2).

\section{Climate Change Adaptation Initiatives in Africa}

Scientific evidence indicates that the earth's climate is rapidly changing, owing to increases in greenhouse gas emissions leading to raised average temperature and altered the amount and distribution of rainfall globally (Dasgupta et al. 2014). There is growing evidence that the effects of climate change are expected to be greater than the global average in sub-Saharan Africa due to projections of a warming trend characterized by the frequent occurrence of extreme heat events with a $4{ }^{\circ} \mathrm{C}$ warming scenario (Serdeczny et al. 2016), increasing aridity, and a decline in rainfall (Belay et al. 2017). Sub-Saharan Africa is particularly vulnerable to these climatic changes because of overdependence on rainfed agriculture on which the livelihoods of a large proportion of the region's population currently depend (Serdeczny et al. 2016).

There are reports of higher drought risks; extreme weather events such as floods, pests, and high temperatures; and diseases faced by farmers in recent years, exacerbating the food crisis in Africa (Mutunga et al. 2017; IPCC 2018). There is evidence 
from the literature that the current impacts are more severe in rural and smallholder farming communities (Cobbinah and Anane 2016) especially in Africa. This presents the logic that an adaptation initiative is promising only if it fulfills the objective of increasing food security, increases resilience, and is adaptive for smallholder farmers (Descheemaeker et al. 2016). Therefore, adaptation is deemed more important in Africa than mitigation (Descheemaeker et al. 2016). There is a need to strengthen adaptive strategies to ensure food security in Africa. Our review categorizes climate change adaptation in Africa under nine (9) key thematic areas including diversification, ecosystem-based adaptation, climate advisories and information, collective action, technological interventions and innovation, credit facilities, change of patterns, insurance, and capacity building.

\section{Diversification}

Different types of diversification initiatives are applied in Africa including sector diversification, agriculture product diversification and crop diversification, treebased diversification, and livelihood diversification to adapt to climate change. Diversification provides smallholder farmers with a diversity of diet and improves their income and nutrition security, particularly in sub-Saharan Africa where rainfed agriculture is rampant. For example, Mauritius diversified agriculture with the rapid expansion of industrialization for exports in textile and the development of tourism to promote sector diversification and crop diversification. Also, the Government of Mauritius widened access to lands to be leased out to small planters specifically for agriculture product diversification (Luximon and Nowbuth 2010). While in Mauritius the initiatives to diversify agricultural products seem to be incentivized by the Government, in Kenya, they are largely driven by smallholder farmers through offfarm employment, leasing of land (Kalungu and Leal Filho 2018), mixed cropping and livestock farming (Mutunga et al. 2017), and introducing new crops that are drought resistant or switch to a different variety of the same crop (Crick et al. 2018).

In Morocco, farmers practice crop diversification with intercropped vegetables and tree-based diversification using high-value crop trees (HVC), e.g., droughttolerant species of fig, almond, and pomegranate and olive varieties (Kmoch et al. 2018). In Ethiopia, farmers practice crop diversification, agricultural product diversification by increasing the integration of crops with livestock, and tree planting. However, reducing the number of meals is common for livelihood diversification to adapt to limited food supply (Belay et al. 2017). In Tanzania, farmers diversify agricultural products by growing vegetables in the offseason and sell livestock during drought, while in South Africa, livelihood diversification and focus on livestock are common in case of crop failure. In Mozambique, farmers diversify to other food sources to meet the dietary needs and shift focus to other means of livelihood beyond agriculture. Farmers in Ghana diversify to enhance food production through multiple cropping, combine improved and local crop varieties, and shift from palm oil to maize and sweet potatoes (Burnham and Ma 2016). Focus on cultivating cash crop (cashew) and engaging in non-farm-based activities, e.g., business, are also common in Ghana. Cashew cultivation is viewed by small landholdings in Ghana as a better livelihood option compared to non-farm-based 
activities (Cobbinah and Anane 2016). To adapt livestock husbandry to the effects of the extreme of climate change, rural communities in sub-Saharan Africa have diversified to goats instead of cattle and sturdy African breeds instead of more productive crossbreeds (Descheemaeker et al. 2016). In northwest Tunisia, small ruminant farms are better able to adopt the organic farming system and to adapt to warming or precipitation increases by switching to heat-tolerant animals like goats or crops such as Sulla (Khaldi et al. 2012).

Crop diversification together with the diversification of income from multiple sources (cash and in-kind, farm, livestock, crops, and off-farm) is considered to be key "buffer strategies" smallholder farmers pursue to deal with risks of climate change to agrarian environments in Africa (Silvestri et al. 2015; Cobbinah and Anane 2016; Burnham and Ma 2016; Belay et al. 2017; Khacheba et al. 2018; Mutunga et al. 2017). The effectiveness of diversification initiative has been observed in food-secure female-headed households who allocate twice as much land to HVC, e.g., fruits, such as mango and oranges, and then their food-insecure counterparts (Silvestri et al. 2015). This concept in Malawi has demonstrated a gender perspective in climate change adaptation that could be a wake-up call to many African countries to enhance women's adaptive capacity and resilience to climate change (Nyasimi et al. 2014). Indigenous fruit tree production for improved nutrition and income is successful in Malawi, Zambia, and Zimbabwe. Fruit consumption has clear health and nutrition benefits such as providing essential micronutrients and protecting against chronic diseases. Even though fruit consumption in Africa is low, fruit trees fulfill a vital role in contributing to food security, because the fruit is consumed seasonally at a time when households run out of food (Kiptot et al. 2014). There is a need to extensively explore diversification through fruit trees across many African countries to enhance food security.

\section{Ecosystem-Based Adaptation}

Ecosystem-based adaptation is the use of biodiversity and ecosystem services as part of an overall adaptation strategy to help farmers adapt to the adverse effects of climate change (Vignola et al. 2015). There is a rapidly growing interest in ecosystem-based adaptation for its potential social, environmental, and economic benefits (e.g., Cerdán et al. 2012; Namirembe et al. 2014; Vignola et al. 2015). Agroforestry provides environmental and social benefits as part of farming livelihoods. In most documented cases of successful agroforestry establishment, tree-based systems are more productive, more sustainable, and more attuned to people's cultural or material needs than treeless alternatives (Mbow et al. 2014). Trees or shrubs on farms and forest-agriculture integration are gaining preference among farmers in Africa. Despite the productivity of agroforestry systems, it has not been fully adopted in many African countries, e.g., Kenya's intention to achieve a 10\% target of tree cover on farmers' acreage is yet to be realized (Oloo 2013). There is a need for more insights into the productivity and environmental performance of agroforestry systems across Africa (Mbow et al. 2014). Agroforestry with leguminous fodder plants to support food requirements for livestock during extreme weather is gaining attention among farmers in sub-Saharan Africa (Cobbinah and Anane 2016). In 
Tanzania, farmers focus on planting trees as hedgerows, while in Nigeria on-farm trees are used to shade crops and animals (Burnham and Ma 2016). Tree-based agroforestry is also popular in Morocco where farmers use bi- or triennial trees like olives to increase tree cover on-farm (Kmoch et al. 2018).

Improved tree fallows using leguminous trees are encouraged in maize fields in Malawi, Zambia, and Zimbabwe as low cash-input agroforestry practices to restore soil fertility (Keil et al. 2005). Studies in semi-arid areas in Tanzania showed that agroforestry tree species producing high-quality litter could enhance post-fallow soil nutrient availability and crop yields through mineralization of soil organic matter and green manure (Kimaro et al. 2008). In Mauritius, farmers promote the use of organic farming, using organic manure which is more resistant to drought and also reduces the risk of floods (Luximon and Nowbuth 2010), and in Kenya, farmers using locally available organic matter prepare organic manure (Oloo 2013). Farmers in Morocco adapt to the effects of climate change like floods by encouraging conservation agriculture through minimum tillage and increase of soil cover (Kmoch et al. 2018). Minimum tillage and crop rotation were observed to increase farm maize productivity by about $26-38 \%$ for minimum tillage and $21-24 \%$ for crop rotation in Zambia (Kuntashula et al. 2014). In sub-Saharan Africa rangeland, farmers practice grazing and rangeland management to enhance manure collection, storage, and application (Descheemaeker et al. 2016).

Planting cover crops and the use of manure for soil conservation to prevent soil erosion and to improve soil fertility respectively are common among smallholder farmers in Tanzania, Kenya, and Ethiopia (Mutunga et al. 2017; Belay et al. 2017; Burnham and Ma 2016). Farmers in Ethiopia are observed to practice both soil and water conservation (Belay et al. 2017). In Burkina Faso, farmers arrange stone lines on-farm and in the field to capture surface runoff for microwater harvesting and to prevent soil erosion due to flash floods, and in South Africa, farmers build bunds along contour lines to slow down water runoff (Burnham and Ma 2016).

\section{Technology and Innovation Adoption}

The adoption of appropriate technologies in small-scale farming is an important response to the effects of climate change and variability, especially in Africa (Kalungu and Leal Filho 2018). Farmers largely apply integrated pest management as a means of pest control (Luximon and Nowbuth 2010). Literature indicates a wide use of technological intervention to enhance adapting dairy farming in Tunisia, e.g., farmers in Tunisia build up fodder reserves in favorable years, increase concentrate distribution, manage nutritional requirements, and promote drinking water ad libitum (Hajer et al. 2018). They are keen on the choice of breed and maximize the use of agri-byproducts as feeds. To improve productivity, farmers in Tunisia enhance irrigation potential at the farm level. Farmers also adjust calving periods by concentrating them within favorable feeding periods (Belay et al. 2017). Building fodder reserves for animals is also documented in Burkina Faso (Burnham and Ma 2016). Farmers in Burkina Faso also overcome the shock of drought by producing dry season vegetables using irrigation and the use of improved seeds. 
In Kenya, farmers in semi-arid regions apply a combination of technological interventions under Framing Technologies, e.g., soil fertility management, irrigation soil conservation, and water management row planting and terracing. There is highlevel awareness on the use of hybrid crop varieties, pesticides, and changing crop variety depending on climate variability (Mutunga et al. 2017; Kalungu and Leal Filho 2018). Planting short seasoned crops and resistant crop variety and feed preservation for farm animals have also been recognized as key adaptive interventions among Kenya farmers (Oloo 2013). Rotation cropping of cereals and legumes and irrigated fruit trees are common in commercially orientated farming systems in Morocco, with agro-silviculture (growing of trees and agriculture crops together in the same lands at the same time) dominating all irrigated farms (Kmoch et al. 2018). There is input intensification in Ethiopia to enhance farm-level productivity (Belay et al. 2017), and in Tanzania, farmers use well irrigation and plant quick maturing and drought-resistant varieties (Burnham and Ma 2016). Framers in South Africa increase distances between crop rows and practice irrigation. Farmers in South Africa also plant late-maturing fruit trees to enhance food availability during low harvests (Burnham and Ma 2016). In Ghana, farmers plant high yield varieties (Belay et al. 2017). In other countries relay cropping and mixed intercropping are practiced. By providing nutrients to crops, these technologies can potentially help farmers improve their soils and incomes, thereby improving food security in Malawi, Zambia, and Zimbabwe (Kiptot et al. 2014).

Farmers in many African countries aim at enhancing farm-level productivity by planting early maturing varieties and drought-tolerant crops and changing crop variety to match prevailing weather conditions, e.g., in Nigeria, Mozambique, Angola, and Kenya among other countries (Burnham and Ma 2016). The use of drought-tolerant maize has been documented in Angola, Benin, Kenya, and many other African countries (Nyasimi et al. 2014). Technological intervention in subSaharan Africa is observed to enhance sustainable intensification in post-harvest storage, choosing adapted crops and cultivars, intercropping and rotation with dualpurpose legumes, water harvesting, and irrigation to adapt local farmers to the adverse effects of climate change to agro-ecosystems. Similarly, technology is expected to enhance the choice for animal types and breeds that are better adapted to heat stress and dry conditions and to improve the storage of food and feed (Descheemaeker et al. 2016).

Moreover, technologies to reduce post-harvest losses are in consideration; e.g., the use of metal silo technology in household maize storage in Kenya has proved effective in protecting stored grains from attack by storage insect pests, sustaining maize supply while reducing the burden on the natural environment (Gitonga et al. 2013; Tefera et al. 2011). Other adaptation technologies promote water allocation efficiency for irrigation. For example, the water-energy-food (WEF) nexus is promoting the uptake of drip irrigation among smallholder farmers in Morrocco (He et al. 2006). WEF technology has been promoted as a demand-side management option for reducing water consumption while maintaining yields, particularly through minimizing nonproductive evaporative losses (Jobbins et al. 2015). In Ethiopia, other technologies that maximize precipitation utilization in dryland are 
promoted, e.g., increasing the length of the fallow period before planting to increase the amount of pre-plant stored water in the soil and retention of large amounts of crop residue on the soil surface to decrease runoff (Woyessa and Bennie 2007).

\section{Climate Advisory and Extension}

Climate advisories and information offer opportunities to inform farmers of climaterelated risks, e.g., agrometeorological advisory program and weather and climate bulletins in Mali, and inform farmers on decisions such as variety selection, planting times, and the timing of inputs in Mali (Carr and Onzere 2018). Access to climate change information and extension services is encouraged in Kenya (Mutunga et al. 2017). However, $76 \%$ still have limited access to agricultural extension services (Kalungu and Leal Filho 2018). Extension services enhance access to information about new agricultural technologies and innovations. The use of weather information by farmers in Ghana is well documented (Belay et al. 2017). The use of early warning signs, weather forecasts, and agricultural extension services are indicated as important in enhancing the adaptation of farmers to climate variability in subSaharan Africa (Descheemaeker et al. 2016; Mbow et al. 2014). In East Africa, climate advisory and extension services remain low among smallholder farmers leading to limited capacity to use climate data (Atela et al. 2018; Singh et al. 2016) and climate illiteracy (Spires et al. 2014). However, the role of ICTs in scaling climate information services (CIS) is gaining attention (Atela et al. 2018). For example, short-term climate information through community worker initiative in Uganda provides 10-day, monthly, and seasonal weather forecasts to farmers on their mobile phones via SMS (Singh et al. 2016).

Access to weather information is observed to significantly influence the likelihood of adopting improved crop varieties, making adjustments in the timing of agricultural activities and investing in improved land management practices, and increasing fertilizer use among farmers in West Africa (Wood et al. 2014). Risk management practices that generate and disseminate agro-advisory services and weather information are important adaptive initiatives in Africa (Nyasimi et al. 2014).

\section{Other Adaptive Initiatives}

Increasing acreage as an initiative to enhance productivity is being practiced in some African countries, e.g., about $46.4 \%$ of the landmass in Mauritius is under agriculture, to enhance the production of crops and livestock (Luximon and Nowbuth 2010). The basis of increasing farm size is to increase food crop production to overcome low food crop productivity by maintaining normal productivity. However, this approach is facing sustainability concerns, e.g., continuous expansion of farmlands with a further clearing of the forest in Ghana has potential implications for deforestation, which will, in turn, exacerbate climate change in Ghana (Cobbinah and Anane 2016). Collective action involving collaboration among farmers is being practiced by local farmers and households. Community center approach to livestock management in Morocco (Kmoch et al. 2018), cooperatives and community-based development projects in South Africa (Belay et al. 2017), and social production and 
natural resource management-related groups in West Africa (Wood et al. 2014) have contributed both to limiting the risks and enhancing the capacity to adapt to climate change.

Change of pattern in planting times or moving animals is considered among some farmers in different areas: planting just before the onset of rains and moving animals, changing planting dates, and planting near a river in Kenya and Ghana (Belay et al. 2017; Mutunga et al. 2017; Descheemaeker et al. 2016); planting date adjustment in Ethiopia, Kenya, and Nigeria; planting early as possible after first rain (Belay et al. 2017; Oloo 2013), moving livestock to other areas, store fodder, and selling animals in South Africa (Belay et al. 2017); seasonal herd migration in sub-Saharan Africa (Descheemaeker et al. 2016); and temporary migration in Tanzania (Belay et al. 2017). Capacity building of climate change adaptation is recognized as a means of enhancing their ability to adopt desired initiatives related to technology adoption and diversification. Building capacity of farmers on climate change adaptation is documented in Mauritius (Luximon and Nowbuth 2010). In Mali, a farmer observer has been trained to enhance the capacity of most farmers in southern Mali (Carr and Onzere 2018). Capacity building of water user associations combined with local knowledge and scientific expertise is common in Morocco (Kmoch et al. 2018). In Zambia, the capacity of farmers is enhanced through conventional agricultural extension systems and participatory farmer interactions (Kuntashula et al. 2014). Insurance as a means of climate change adaptation is at trial in sub-Saharan Africa (SSA) to address climate-related risks faced by farmers (Descheemaeker et al. 2016). Weather-based index insurance is being tried in Mali (Carr and Onzere 2018). Adaptation planning in the form of insurance, with or without external support, is being tried in Kenya and Senegal (Crick et al. 2018). However, these products in general face low rates of adoption across SSA due to weakness of regulatory environment and financial facilities, basis risk, quality and availability of weather data, capacity building of stakeholders (farmer, insurer, and regulator), and lack of innovation for local adaptation and scalability (Ntukamazina et al. 2017).

The use of credit facilities has also been documented in Kenya (Mutunga et al. 2017) and Mauritius among other countries (Luximon and Nowbuth 2010). A study in Nigeria found a positive impact of commercial bank credits to food security by up to $8 \%$ (Osabohien et al. 2018). However, there is evidence that traditional credit use, among smallholder farmers, is extremely low in SSA (Adjognon et al. 2017), pointing to weak or no policy across many countries to enhance implementation.

\section{Policy Initiatives for Climate Change Adaptation}

Climate change is progressively hurting agricultural production in Africa (Kalungu and Leal Filho 2018; Crick et al. 2018; Mutunga et al. 2017; Belay et al. 2017; Burnham and Ma 2016). Adoption of suitable adaptation strategies is thus a prerequisite to supporting the majority of smallholder farmers in reducing the effects of climate change (Hajer et al. 2018; Cobbinah and Anane 2016; Belay et al. 2017; Kmoch et al. 2018). Many factors, among them, are policies and markets and have 
been identified to define responses of the farmers to climate change shocks (Peter et al. 2017; Hummel 2016; Magnan et al. 2011; Kalame et al. 2009).

\section{Policy to Enhance Diversification and Risk Management}

Climate change adaptation policy in Mauritius made available 200 acres of agricultural land widening access to land for lease to small planters for agriculture diversification enhancing food production in the country (Luximon and Nowbuth 2010). Mauritius government advanced some incentives to farmers to support diversification, e.g., agricultural credit from the bank and subsidy on the price of farm input, guaranteed price for some farm produce, and offered some facilities to livestock breeders. Mauritius has the policy to limit food products locally produced to local consumption, while the country exploits the opportunity of cross-border initiatives (CBI) set by FAO with Madagascar, Mozambique, and Tanzania to increase production for domestic consumption (Luximon and Nowbuth 2010). A similar policy on price control also succeeded in Tunisia by reducing the exposure of Tunisian farmers to the food price volatility in the world markets and cautioning local households from the risk of scarcity in food supply (Chemingui et al. 2001). Participating in trade relations with the European Union (EU) and enhanced political cooperation has promoted the diversification of income sources from the trade of agricultural products (Chemingui et al. 2001).

\section{Multi-sectoral Policies on Climate Advisory and Extension}

In Namibia, the national-level development policy context of Vision 2030 guides Namibia's national, long-term development related to climate change adaptation. Climate change is mainstreamed in agriculture, disaster response strategies, and marine resources. The policy strengthens Namibia's meteorological services by supporting the work of the National Climate Change Committee in mainstreaming climate change adaptation and strengthening capacities to respond to it (Crawford and Terton 2016). The National Climate Change Strategy and Action Plan (NCCSAP) in Namibia has a direct link to enhancing climate change adaptation initiatives by setting up adaptation action on diversification of crops to adapt to erratic rainfall. It focuses on the increased use of improved crop varieties, conservation of indigenous livestock breeds, and diversification of livelihoods through tourism and wildlife conservancies (Crawford and Terton 2016). The policy aims to enhance capacities and synergies at individual, local, institutional, national, regional, and systematic levels to ensure successful implementation of climate change response activities and adequate funding resources for effective adaptation (Crawford and Terton 2016).

\section{National-Level Policies for Adoption of Ecosystem-Based Initiatives}

Policies on restoration or management of biodiversity and ecosystem services could confer multiple adaptive benefits, e.g., the use of shade trees in coffee farms (i.e., producing coffee as an agroforestry system), and could ensure the continued provision of key ecosystem services like pollination, natural pest control, conservation of water and soils, etc. as well as buffering coffee from extreme temperatures and 
rainfall, leading to more stable production under climate-related stresses (Vignola et al. 2015). Despite the growing interest in ecosystem-based adaptation, there has been little discussion of how this initiative could be enhanced among smallholder farmers while ensuring the continued provision of ecosystem services on which farming depends (Vignola et al. 2015). Policies on land use planning, forestagriculture integration, and landscape-based adaptation are in line with enhancing local adoption of an ecosystem-based approach to climate change adaptation (Mbow et al. 2014). In South Africa, municipal climate adaptation plans use a sectoral approach to encourage greater interaction among different sectors and provided a clearer understanding of the needs and roles in climate adaptation (Roberts 2010). A specific case where policy implementation has been seen to influence the adaptation of technology and diversification initiatives was seen in the implementation of Global-GAP policy in the production of French beans in Kenya. The policy expected farmers to comply with certain climate adaptation strategies. The implementation supported changing crop variety, water harvesting, finding off-farm jobs, and soil conservation (Peter et al. 2017). The National Adaptation Plan 2015-2030 was developed by the Kenyan government to enhance adaptation capacity at macro-level. From the thematic perspective, Kenya's National Climate Change Action Plan (NCCAP 2018-2022) has prioritized adaptation initiatives focused on food security (GOK 2018).

\section{Regional-Level Policies and Treaties}

Regional treaties and international policies affect people's mobility in the context of climate change, and environmental change is strongly influenced by different international, regional, and national policies in the fields of migration, development, and environment. The crucial importance of mobility and migration within the West African region means that subregional initiatives, treaties, and regulations are particularly significant (Hummel 2016). Economic Community of West African States (ECOWAS)s common approach on migration enabling citizens to enter freely, reside, and settle in member countries is particularly important to livestock farmers in Senegal and Mali as one possible response to changing ecosystems (Hummel 2016).

Some regional commitments to enhance food security including the Comprehensive Africa Agriculture Development Programme (CAADP) and the subsequent Malabo Declaration on Accelerated Agricultural Growth and Transformation for Shared Prosperity and Improved Livelihoods are in place. However, the commitment to achieve the targets of the agreements may need upscaling. For example, the implementation of the agreement to allocate at least $10 \%$ of public expenditure to agriculture in Malabo Declaration remains low, with only Botswana and three other African countries including South Africa, Malawi, and Senegal engaging in public spending on agriculture worth above 10\% (Mink 2016). Similarly, the implementation of the Paris Agreement to combat climate change by accelerating and intensifying climate actions remains weak with most countries making only small and cosmetic changes in transforming Intentional Nationally Determined Contributions (INDCs) to Nationally Determined Contributions (NDCs) (AFDB 2015). 


\section{National-Level Policies for Technology Adoption}

Policies aligned to climate change adaptation could influence the adoption of technology. For example, Senegal Agriculture Programme was established in 2006 in response to an increase in outmigration from rural areas. This policy aimed at enhancing the use of technology in agriculture to generate sustainable incomes to attract young people to stay in their villages, enhancing rural development (Hummel 2016). Institutionalization of climate change adaptation into policy has the potential to enhance agricultural productivity. In Durban in South Africa, the climate adaptation policy ensuring that $50 \%$ of the food consumed by the rural poor is locally produced has led to the adoption of technology and diversification initiatives enhancing agricultural productivity (Roberts 2010). Policy context on climate change and agriculture in Ghana demonstrates a strong focus on the application of technology and innovation in agriculture as an engine for growth and development. Ghana's Shared Growth Development Agenda (GSGDA 2010 2013) highlighted the importance of facing climate change technological solutions such as drought-tolerant crop varieties and a transformation from rain-fed to irrigated agriculture, as well as reducing deforestation through agricultural expansion to improve the robustness of the sector to adapt to climate change (Sarpong and Anyidoho 2012). The government of Ghana has embarked on the implementation of a policy on reforestation through large-scale plantation development and small-scale on-farm regeneration activities to promote adaptation to climate change through ecosystem-based approaches. A similar initiative in reforestation has also been tried by the government of Burkina Faso (Kalame et al. 2009) and Kenya (Oloo 2013). However, there is fear that without proper planning, coordination, funding, and incentives to farmers for adoption, failure of reforestation policy could lead to large-scale deforestation and degradation, like in the case of Burkina Faso (Kalame et al. 2009).

\section{Regional Policies and Trade-offs}

In Morocco, food security trade-off policies are applied at the national level. Sufficiently transparent pricing model, subsidy, import substitution (increasing domestic production and reducing imports), intensification, and subsidizing farmers to grow cereals, either through deficiency payments or targeted input subsidies, have made cereal farming more lucrative (Magnan et al. 2011). Nonetheless, countries should observe that the application of trade-off policies does not contravene World Trade Organization regulations. Mauritius is often referred to as one of the very few developing countries to have overcome poverty and hunger by participating successfully in the globalization of the world market. Application of policy that enhances sector diversification to export-oriented agricultural diversification and industrialization aimed at reducing the dependence on food imports and increasing national food self-sufficiency. The implementation of the policy led to the attainment of national self-sufficiency in potatoes (Koop 2005). Policy on the modernization of agriculture and insulation of local farmers from external competition has permitted Tunisia to substantially increase its outputs, yields, and self-sufficiency rates in products considered as being strategic, such as cereals, vegetables, oil, and livestock 
products (Chemingui et al. 2001). Food self-sufficiency policy has influenced the development of irrigated farming in Botswana as a possible complement to rain-fed agriculture to enhance the production of cereals, mainly maize and sorghum (Lado 2001). The model food security pathway for African countries is summarized in Fig. 3.

Effect

Food Security

Reduced \% undernourishment

Indicators

Adaptation initiatives

Role of stakeholders

Strategy Background

Constraints

Climate change shocks

Balanced, coordinated and aligned to local knowledge. Responds to climate change shocks at local and regional contexts

Climate change policy

Local/National Government
Increased food production, enhanced food access, food utilization, food stability

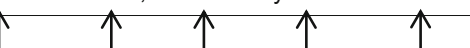

Climate change adaptation

Farmers

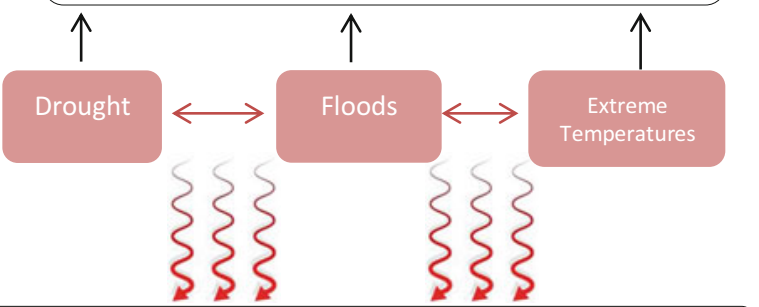

To enhance capacity to adapt to climate change for food security

National level Objective

Fig. 3 A conceptual model of climate change adaptation pathway for food security in Africa. Balancing between climate change policy and adaptation (Authors own) 


\section{Conclusion}

High prevalence of undernourishment was observed in six countries, all in SSA including Chad, Liberia, Central African Republic, the Democratic Republic of the Congo, Zambia, and Zimbabwe. Countries with a high land acreage under cereal production recorded reduced undernourishment as observed in Nigeria, Sudan, Ethiopia, Tanzania, and Niger. Five countries including Niger, Eritrea, Malawi, Swaziland, and Kenya experienced extreme climate variability in the last 10 years including droughts, floods, and extreme temperatures. Despite the extreme climate variability, Niger, Eritrea, Malawi, and Swaziland still registered average to high crop production index, an indication of effective climate change adaptation. Niger demonstrated effective adaptation for food security by registering the highest crop production index in extreme climate variability. However, Kenya appears to be the most predisposed by registering both high climate variability and below average crop production index.

Diversification and technology adoption were key strategies applied across countries. However, the uptake of technology by smallholder farmers is still low across many countries in SSA. There are efforts to mainstream climate change policy in agriculture at local, national, and regional levels to enhance technology adoption, capacity building, and funding. There is a need to strengthen policy to promote climate advisory and extension, climate literacy, and capacity to use ICTs to disseminate climate information services. A lack of commitment by governments to regional agreements to enhance food security and climate action has been observed. Only Botswana, South Africa, Malawi, and Senegal had spent on agriculture worth above $10 \%$ of national expenditure in line with the Malabo Declaration. Similarly, the implementation of the Paris Agreement to combat climate change by accelerating and intensifying climate actions remains to be weak in most countries.

The chapter maps the patterns of climate variability and undernourishment prevalence and establishes the linkages between policy initiatives and adaptation actions. Future academic explorations may focus on gaps in gender perspectives in climate change adaptation and effective ICTs for the dissemination of climate information services among smallholder farmers in SSA.

Acknowledgments Strathmore University provided information on the call for the research. Food and Agriculture Organization of the United Nation (FAO) through the online platform provided information on food security indicators and desktop data for analysis and World Development Indicator (WDI) for Environment and Climate Change data through the online data portal.

\section{References}

Abegunde VO, Sibanda M, Obi A (2019) The dynamics of climate change adaptation in subSaharan Africa: a review of climate-smart agriculture among small-scale farmers. Climate 7:123. https://doi.org/10.3390/cli7110132

Adjognon SG, Liverpool-Tasie LSO, Reardon TA (2017) Agricultural input credit in sub-Saharan Africa: telling myth from facts. Food Policy 67:93-105 
AFDB (2015) Transitioning from INDCs to NDCs in Africa. AfDB CIF knowledge series, (11/ 2015). Africa Development Bank Group, Abidjan

AGRA (2014) Africa agriculture status report: climate change and smallholder agriculture in subSaharan Africa. AGRA, Nairobi

Atela J, Gannon KE, Crick F (2018) Climate change adaptation among female-led micro, small and medium enterprises in semi-arid areas: a case study from Kenya working paper. In: Leal Filho W (ed) Handbook of climate change resilience. Springer, Cham, pp 1-18. https://doi.org/10.1007/ 978-3-319-71025-9 97-1

Belay A, Recha JW, Woldeamanuel T, Morton JF (2017) Smallholder farmers' adaptation to climate change and determinants of their adaptation decisions in the Central Rift Valley of Ethiopia. Agric Food Secur 6:1-13. https://doi.org/10.1186/s40066-017-0100-1

Bongaarts J (2009) Human population growth and the demographic transition. Philos Trans R Soc B Biol Sci 364:2985-2990

Brandt M, Rasmussen K, Peñuelas J, Tian F, Schurgers G, Verger A, Mertz O, Palmer RBJ, Fensholt R (2017) Human population growth offsets climate-driven increase in woody vegetation in subSaharan Africa. Nat Ecol Evol 1:1-6

Burnham M, Ma Z (2016) Linking smallholder farmer climate change adaptation decisions to development. Clim Dev 8:289-311. https://doi.org/10.1080/17565529.2015.1067180

Carr ER, Onzere SN (2018) Really effective (for $15 \%$ of the men): lessons in understanding and addressing user needs in climate services from Mali. Clim Risk Manag 22:82-95. https://doi. org/10.1016/j.crm.2017.03.002

Cerdán CR, Rebolledo MC, Soto G, Rapidel B, Sinclair FL (2012) Local knowledge of impacts of tree cover on ecosystem services in smallholder coffee production systems. Agric Syst 110:119 130. https://doi.org/10.1016/j.agsy.2012.03.014

Chemingui M, Chemingui MA, Thabet C (2001) Internal and external reforms in agricultural policy in Tunisia and poverty in rural area Facilitating negotiations on the Arab Customs Union View project Trade structure and performance profile for Arab countries View project Internal and External Reform. https://www.researchgate.net/publication/229027151

Cobbinah PB, Anane GK (2016) Climate change adaptation in rural Ghana: indigenous perceptions and strategies. Clim Dev 8:169-178. https://doi.org/10.1080/17565529.2015.1034228

Conceição P, Levine S, Lipton M, Warren-Rodríguez A (2016) Toward a food secure future: ensuring food security for sustainable human development in sub-Saharan Africa. Food Policy 60:1-9. https://doi.org/10.1016/j.foodpol.2016.02.003

Crawford A, Terton A (2016) Review of current and planned adaptation action in Namibia. International Development Research Centre. http://www.idrc.ca/cariaa

Crick F, Eskander SMSU, Fankhauser S, Diop M (2018) How do African SMEs respond to climate risks? Evidence from Kenya and Senegal. World Dev 108:157-168. https://doi.org/10.1016/j. worlddev.2018.03.015

Dasgupta P, Morton JF, Dodman D, Karapinar B, Meza F, Rivera-Ferre MG, Toure Sarr A, Vincent KE (2014) Rural areas. In: Field CB, Barros VR, Dokken DJ, Mach KJ, Mastrandrea MD, Bilir TE, Chatterjee M, Ebi KL, Estrada YO, Genova RC, Girma B, Kissel ES, Levy AN, MacCracken S, Mastrandrea PR, White LL (eds) Climate change 2014: impacts, adaptation, and vulnerability. Part A: global and sectoral aspects. Contribution of working group II to the fifth assessment report of the Intergovernmental Panel on Climate Change. Cambridge University Press, Cambridge, pp 613-657

Descheemaeker K, Oosting SJ, Homann-Kee Tui S, Masikati P, Falconnier GN, Giller KE (2016) Climate change adaptation and mitigation in smallholder crop-livestock systems in sub-Saharan Africa: a call for integrated impact assessments. Reg Environ Chang 16:2331-2343. https://doi. org/10.1007/s10113-016-0957-8

Gitonga ZM, De Groote H, Kassie M, Tefera T (2013) Impact of metal silos on households' maize storage, storage losses and food security: an application of a propensity score matching. Food Policy 43:44-55

GOK (2018) Republic of Kenya Ministry of Environment and Forestry National Climate Change action plan 2018-2022, vol I. Ministry of Environment and Forestry, Nairobi 
Hajer A, Mohsen BS, Hatem A, Hichem K, Mahouachi M, Beckers Y, Hammami H (2018) Climate change-related risks and adaptation strategies as perceived in dairy cattle farming systems in Tunisia. Clim Risk Manag 20:38-49. https://doi.org/10.1016/j.crm. 2018.03.004

He L, Tyner WE, Doukkali R, Siam G (2006) Policy options to improve water allocation efficiency: analysis on Egypt and Morocco. Water Int 31:320-337

Hummel D (2016) Climate change, land degradation and migration in Mali and Senegal - some policy implications. Migr Dev 5:211-233. https://doi.org/10.1080/21632324.2015. 1022972

IPCC (2007) Climate change 2007: synthesis report. In: Pachauri RK, Reisinger A (eds) Contribution of working groups I, II and III to the fourth assessment report of the intergovernmental panel on climate change [core writing team]. IPCC, Geneva, Switzerland, p 104

IPCC (2013) Climate change 2013: the physical sciences basis. IPCC, Geneva, Switzerland

IPCC (2018) Global warming of 1.5 oC. In IPCC - Sr15. https://report.ipcc.ch/sr15/pdf/sr15_spm final.pdf\%0A http://www.ipcc.ch/report/sr15/

Jobbins G, Kalpakian J, Chriyaa A, Legrouri A, El Mzouri EH (2015) To what end? Drip irrigation and the water-energy-food nexus in Morocco. Int J Water Res Dev 31:393-406

Kalame FB, Nkem J, Idinoba M, Kanninen M (2009) Matching national forest policies and management practices for climate change adaptation in Burkina Faso and Ghana. Mitig Adapt Strateg Glob Chang 14:135-151. https://doi.org/10.1007/s11027-008-9155-4

Kalungu JW, Leal Filho W (2018) Adoption of appropriate technologies among smallholder farmers in Kenya. Clim Dev 10:84-96. https://doi.org/10.1080/17565529.2016.1182889

Keil A, Zeller M, Franzel S (2005) Improved tree fallows in smallholder maize production in Zambia: do initial testers adopt the technology? Agrofor Syst 64:225-236

Khacheba R, Cherfaoui M, Hartani T, Drouiche N (2018) The nexus approach to water-energyfood security: an option for adaptation to climate change in Algeria. Desalin Water Treat 131:30-33. https://doi.org/10.5004/dwt.2018.22950

Khaldi R, Mohamed J, Khaldi G (2012) Impacts of climate change on the small ruminants farming systems in northwestern Tunisia and adaptation tools. In: New approaches for grassland research in a context of climate and socio-economic changes. CIHEAM, Zaragoza, pp 427-431

Kimaro AA, Timmer VR, Chamshama SAO, Mugasha AG, Kimaro DA (2008) Differential response to tree fallows in rotational woodlot systems in semi-arid Tanzania: post-fallow maize yield, nutrient uptake, and soil nutrients. Agric Ecosyst Environ 125:73-83

Kiptot E, Franzel S, Degrande A (2014) Gender, agroforestry and food security in Africa. Curr Opin Environ Sustain 6:104-109. https://doi.org/10.1016/j.cosust.2013.10.019

Kmoch L, Pagella T, Palm M, Sinclair F (2018) Using local agroecological knowledge in climate change adaptation: a study of tree-based options in northern Morocco. Sustainability (Switzerland) 10:3719. https://doi.org/10.3390/su10103719

Koop K (2005) Food security in the era of globalisation-the case of Mauritius 49 governance and food security in the era of globalization: the case of Mauritius, vol II. https://halshs.archivesouvertes.fr/halshs-00265114

Kuntashula E, Chabala LM, Mulenga BP (2014) Impact of minimum tillage and crop rotation as climate change adaptation strategies on farmer welfare in smallholder farming systems of Zambia. J Sustain Dev 7:95-110. https://doi.org/10.5539/jsd.v7n4p95

Lado C (2001) Environmental and socio-economic factors behind food security policy strategies in Botswana. Dev South Afr 18:141-168. https://doi.org/10.1080/037/68350120041875

Lasco RD, Delfino RJP, Catacutan DC, Simelton ES, Wilson DM (2014) Climate risk adaptation by smallholder farmers: the roles of trees and agroforestry. Curr Opin Environ Sustain 6:83-88. https://doi.org/10.1016/j.cosust.2013.11.013

Luximon Y, Nowbuth MD (2010) A status of food security in Mauritius in face of climate change. Eur Water 32:3-14

Magnan N, Lybbert TJ, McCalla AF, Lampietti JA (2011) Modeling the limitations and implicit costs of cereal self-sufficiency: the case of Morocco. Food Secur 3:49-60. https://doi.org/10. 1007/s12571-010-0103-2 
Mbow C, Van Noordwijk M, Luedeling E, Neufeldt H, Minang PA, Kowero G (2014) Agroforestry solutions to address food security and climate change challenges in Africa. Curr Opin Environ Sustain 6:61-67. https://doi.org/10.1016/j.cosust.2013.10.014

Mink SD (2016) Findings across agricultural public expenditure reviews in African countries, vol 1522. International Food Policy Research Institute, Washington, DC

Mutunga EJ, Ndungu CK, Muendo P (2017) Smallholder farmers perceptions and adaptations to climate change and variability in Kitui County, Kenya. J Earth Sci Clim Change 8(3). https://doi. org/10.4172/2157-7617.1000389

Namirembe S, Leimona B, Van Noordwijk M, Bernard F, Bacwayo KE (2014) Co-investment paradigms as alternatives to payments for tree-based ecosystem services in Africa. Curr Opin Environ Sustain 6:89-97. https://doi.org/10.1016/j.cosust.2013.10.016

Ntukamazina N, Onwonga RN, Sommer R, Rubyogo JC, Mukankusi CM, Mburu J, Kariuki R (2017) Index-based agricultural insurance products: challenges, opportunities and prospects for uptake in sub-Sahara Africa. J Agric Rural Dev Trop Subtrop 118(2):171-185

Nyasimi M, Amwata D, Hove L, Kinyangi J, Wamukoya G (2014) Evidence of impact: climatesmart agriculture in Africa. http://www.ccafs.cgiar.org

Oloo G (2013) Evaluation of climate change adaptation strategies and their effect on food production among smallholder farmers in Bungoma County, Kenya. Egerton

Osabohien R, Afolabi A, Godwin A (2018) An econometric analysis of food security and agricultural credit facilities in Nigeria. Open Agric J 12(1):227-239

Peter SO, Chris AO, John M, Rose AN (2017) Effect of global-GAP policy on smallholder French beans farmers climate change adaptation strategies in Kenya. Afr J Agric Res 12:577-587. https://doi.org/10.5897/ajar2017.12149

R Core Team (2020) R: a language and environment for statistical computing. R Foundation for Statistical Computing, Vienna, Austria

Roberts D (2010) Prioritizing climate change adaptation and local level resilience in Durban, South Africa. Environ Urban 22:397-413. https://doi.org/10.1177/0956247810379948

Sarpong DB, Anyidoho NA (2012) Climate change and agricultural policy processes in Ghana. http://www.future-agricultures.org

Serdeczny O, Adams S, Baarsch F, Coumou D, Robinson A, Hare W, Schaeffer M, Perrette M, Reinhardt J (2016) Climate change impacts in sub-Saharan Africa: from physical changes to their social repercussions. Reg Environ Chang 17:1585-1600

Silvestri S, Sabine D, Patti K, Wiebke F, Maren R, Ianetta M, Carlos QF, Mario H, Anthony N, Nicolas N, Joash M, Lieven C, Rufino MC (2015) Households and food security: lessons from food secure households in East Africa. Agric Food Secur 4:23. https://doi.org/10.1186/s40066015-0042-4

Singh C, Urquhart P, Kituyi E (2016) From pilots to systems: barriers and enablers to scaling up the use of climate information services in smallholder farming communities. CARIAA working paper no. 3. International Development Research Centre, Ottawa/London. http://www.idrc.ca/ cariaa

Spires M, Shackleton S, Cundill G (2014) Barriers to implementing planned community-based adaptation in developing countries: a systematic literature review. Clim Dev 6:277-287. https:// doi.org/10.1080/17565529.2014.886995

Tefera T, Kanampiu F, De Groote H, Hellin J, Mugo S, Kimenju S, Beyene Y, Boddupalli PM, Shiferaw B, Banziger M (2011) The metal silo: an effective grain storage technology for reducing post-harvest insect and pathogen losses in maize while improving smallholder farmers' food security in developing countries. Crop Prot 30:240-245

UNFCC (2006) Technologies for adaptation to climate change. Climate Change Secretariat (UNFCCC), Bonn, Germany

Vignola R, Harvey CA, Bautista-Solis P, Avelino J, Rapidel B, Donatti C, Martinez R (2015) Ecosystem-based adaptation for smallholder farmers: definitions, opportunities and constraints. Agric Ecosyst Environ 211:126-132. https://doi.org/10.1016/j.agee.2015.05.013 
Wood SA, Jina AS, Jain M, Kristjanson P, DeFries RS (2014) Smallholder farmer cropping decisions related to climate variability across multiple regions. Glob Environ Chang 25:163172. https://doi.org/10.1016/j.gloenvcha.2013.12.011

Woyessa YE, Bennie ATP (2007) Tillage-crop residue management and rainfall-runoff relationships for the Alemaya catchment in Eastern Ethiopia. Sh Afr J Plant Soil 24:8-15

Open Access This chapter is licensed under the terms of the Creative Commons Attribution 4.0 International License (http://creativecommons.org/licenses/by/4.0/), which permits use, sharing, adaptation, distribution and reproduction in any medium or format, as long as you give appropriate credit to the original author(s) and the source, provide a link to the Creative Commons license and indicate if changes were made.

The images or other third party material in this chapter are included in the chapter's Creative Commons license, unless indicated otherwise in a credit line to the material. If material is not included in the chapter's Creative Commons license and your intended use is not permitted by statutory regulation or exceeds the permitted use, you will need to obtain permission directly from the copyright holder.

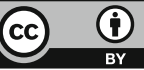

